\title{
Semiotika Kehidupan Masyarakat Modern dalam Video Chained to the Rhythm.
}

\author{
Renny Candradewi Puspitarini \\ Universitas Panca Marga Probolinggo \\ E-mail: renny.candradewi@upm.ac.id
}

\begin{abstract}
Abstrak. Tulisan ini mencoba membuktikan bahwa kehidupan pasca modern saat ini bisa dieksplorasi dengan mempelajari lagu apa yang diputar pada tahun tersebut. Pada tahun 2017, lagu Katy Perry berjudul "Chained to The Rhythm" memecahkan rekor di banyak tangga lagu internasional tidak hanya karena lirik dan videonya tetapi juga kekhasannya yang memantik rasa ingin tahu mengingat makna tidak pernah benar-benar tekstual. Makna juga social-poitis yang maka itu dimensi semiolagi berperan penting. Tulisan ini menggunakan metode semiotic dengan analisis semiotika yang dapat membantu memami nilai-nilai yang terdeviasi, pada tingkat apa, dan apa dampaknya. Digabung dengan studi literatur, untuk menyematkan obyek dari satu syntagma ke sintagma lain. Keduanya baik lirik dan video yang diputar dalam Chained to the Rhythm Katy Perry menjadi contoh komplit dari paradigma ciri kehidupan pasca-modernisme.
\end{abstract}

Kata kunci: Teori Media Ekologi, Analisis semiotika, Komunikasi pesan sosial video, Post-modern

\begin{abstract}
The articles argues that the post-modern life in current state can be explored some more by studying what songs are played within the years. In 2017, Katy Perry's Chained to The Rhythm becomes hit record-breaking not only for its lyrics and video but also for its intriguing feature since meanings never just textual. They are also sociopolitical and it is upon this dimension semiology prevails. The writing employs method of semiotic with semiotic analysis that can help understand what norms are being deviated from, to what extent, and possibly, to what effect. Combined with literature study, the article finds visual metaphor exist predominantly side by side with the lyrics during the video played in the background to insert and superimpose objects in one syntagma into another. Both lyrics and video played in Katy Perry's Chained to the Ryhthm is completed by a unit from the paradigm of the post-modern life characteristics.
\end{abstract}

\section{Keywords: Media Ecology Theory, Semiotic Analysis, Social message, communication from video, Post-modern}

\section{Pendahuluan}

Charles Kennedy mengatakan musik dan politik pada intinya juga komunikasi. Musik dapat menjadi cermin kondisi sosial budaya bahkan politik yang terjadi di jaman itu ("Tributes paid to Charles Kennedy," 2015). Di Indonesia, musisi yang pertama kali mengsinergikan realitas politik dengan musik ialah Iwan Fals. Dapat dengan mudah kita temukan karya-karya Iwan Fals yang memuat kritik terhadap rezim orde baru (Awe and Fals, 2005, pp. 1-25). Dalam lagunya berjudul, manusia setengah dewa, Iwan Fals hendak mengingatkan betapa mulianya kedudukan sebagai wakil rakyat di MPR dan DPR. Hal ini juga berfungsi sebagai kritis agar wakil rakyat ingat selalu pada majikannya yakni rakyat. Penyimpangan yang terjadi ialah ketika 
anggota dewan alih-alih sebagai pembela kepentingan rakyat justru menjadi kelompok orang yang menginginkan rakyat agar menjadi bawahannya dan harus tunduk dengan segala keinginan anggota dewan (Nadjib, 2015). Dengan demikian, wakil rakyat dapat bertindak seyogyanya membela dan mengedepankan kepentingan rakyat. Bukan bertindak sebaliknya yakni menyalahgunakan wewenang yang dititipkan rakyat (Pawito, 2005).

Iwan Fals terbukti piawai dalam menuangkan kritis pada rezim orde baru. Ia pun berhasil mendapatkan perhatian orde baru. Penguasa pada waktu itu cukup gelisah dengan narasi yang dikuak oleh Iwan Fals dan dituangkan dalam lirik-lirik cerdas nan apik dalam suatu lagu yang saat itu laris manis. Pada akhirnya, karena kejujurannya Iwan Fals terpaksa mendekam di penjara sebagai tahanan politik dan korban rezim orde baru. Saat ini Iwan Fals telah bebas dan tampil dengan nama lagulagu yang lebih bernuansa romansa daripada bermuatan politis (Subhan SD, 2018). Green Day secara denotatif menyebut realitas politik dan sosial dalam liriknya yang berjudul "American Idiot" (Diomena and Suyanto, 2015). Meskipun lagu American Idiot banyak ditolak oleh publik Amerika Serikat karena liriknya yang kontroversial, lagu ini mengungkapkan sikap penulis lagu terhadap kebijakan pemerintahan George W Bush sebagaimana juga sejumlah isu politik dan sosial yang tengah hangat. judul lagu tersebut mewakili opini penulis lagu yang mencoba menyampaikan pandangannya terhadap para politisi dan media yang seolah mendikte publik tentang apa yang harus mereka lakukan, apa yang harus dibeli hingga apa yang harus dipercayai. Penulis lagu dengan tegas menyatakan tidak ingin publik menjadi sekumpulan orang bodoh karena mempercayai hal-hal yang pemerintah katakan. Penulis lagu juga mengingatkan hal yang dilakukan pemerintah AS saat itu dapat membuat publik AS dibenci oleh seluruh orang di dunia sekaligus diasingkan oleh dunia internasional ("Green Day song meanings: American Idiot," n.d.).

Musik selalu menjadi cerminan dari peristiwa-peristiwa yang terjadi pada periode musik tersebut dibuat. Hal yang sama juga terjadi pada beberapa musisi di dunia. Nyatanya beberapa musisi di dunia juga menggunakan fungsi musik sebagai kritik terhadap pemerintah. Begitu banyak nama musisi yang menuangkan kritiknya pada rezim yang sedang berkuasa. Iwan Fals dan Green Day menjadi acuan utama di tengah-tengah musisi lain dengan musikalitas yang sama namun sedikit sekali yang mendapat perhatian serius dari akademisi.

Katy Perry menjadi salah satu musisi yang mengikuti jejak Green Day dan Iwan Fals, katakanlah secara tidak langsung. Ketika menulis lagu Chained to The Rhythm, Amerika Serikat saat itu tengah melaksanakan pemilu presiden yang kemudian dimenangi oleh Donald Trump. Cara Donald Trump menjalankan administrasi memang cukup mengundang kontroversi. Layaknya suatu reality show, publik AS memang sedang menampilkan panggung politik paling dramatis sejak Ronald Reagan berkuasa. Dikaitkan dengan peristiwa yang mengikuti pasca terpilihnya Donald Trump sebagai presiden AS, maka dapat kita cermati beberapa adegan yang mengilustrasikan atau melambangkan gambaran impilsif dari kebijakan AS pada negara tetangganya seperti New Mexico terkait dengan arus imigran gelap dari New Mexico ke Amerika Serikat. Menggunakan analisis semiotika dalam menelaah teks dalam lirik serta lambang dalam video musik "Chained to the Rhythm", artikel ini dapat mengungkap makna yang mendesak disampaikan pada publik berkaitan dengan perpaduan antara politik dan kehidupan masyarakat di era post-modern. Tulisan ini 
juga berpendapat bahwa video musik Chained to the Rhythm, Katy Perry berusaha mengkomunikasikan kekacauan dan mengkritik kehidupan masyarakat modern yang penuh dengan masalah di tengah-tengah kemajuan informasi dan teknologi yang pesat. Dengan menggunakan metode semiotika, jawaban makna dibalik musik video Chained to the Rhythm ialah kritik terhadap kehidupan post-modern yang berada di luar kendali. Tulisan ini bertujuan untuk menambah literatur yang mengulas tentang postmodernisme. Era postmodern secara general ddipandang sebagai momentum merayakan keberagaman. Kebenaran yang tunggal, global dan universal kini mulai digugat keabsahannya. Keberagaman pikiran dan cara pandang sebagai konsekuensi globalisasi, mulai digeser dan diselipkan dengan keberagaman. Narasi modernisme banyak ditangkap dalam rekaman video Chained to the Rhythm. Dengan mengananalisis lagu ini, mengajak menemukan narasi-narasi baru yang perlu menggugat kebungkamanannya dan muncul sebagai diskursus kebudayaan postmodern.

\section{Tinjauan Pustaka}

\section{Teori Ekologi Media}

Penelitian ini berangkat dari teori komunikasi massa McLuhan tentang Ekologi Media/Determinisme Teknologi (Griffin, 2014) yang merupakan teori yang tidak bisa dilepas dari dinamika berkembangnya media baru saat ini. Media mempengaruhi setiap tindakan di dalam masyarakat termasuk perkembangan Globalisasi dengan kecanggihan teknologinya mampu mempengaruhi bagaimana individu dalam masyarakat berpikir, merasa serta bertindak. Termasuk pengaruh pada budaya manusia dalam berkomunikasi. Teknologi media komunikasi menentukan budaya dalam beberapa hal yang sangat mendasar sesuai dengan konsep the medium is the message (Littlejohn and Foss, 2009)

Media memperbaiki persepsi kita dan mengelola pengalaman kita dengan pesatnya perkembangan teknologi informasi dan komunikasi yang membuat segalanya serba viral dan instan. Teknologi sebagai peralatan yang memudahkan kerja manusia membuat budaya ingin selalu dipermudah dan menghindari kerja keras maupun ketekunan. Teknologi juga membuat seseorang berpikir tentang dirinya sendiri. Jiwa sosialnya melemah sebab merasa bahwa tidak memerlukan bantuan orang lain jika menghendaki sesuatu, cukup dengan teknologi sebagai solusinya. Akibatnya, tak jarang kepada tetangga dekat kurang begitu akrab karena telah memiliki komunitas sendiri, meskipun jarak memisahkan, namun berkat teknologi tak terbatas ruang dan waktu.

Selain itu, Media mengikat dunia bersama-sama yang ditandai dengan munculnya internet sebagai pemersatu dunia dalam genggaman tangan, menjadi alat media yang mengikat dunia bersama-sama dan membuat dunia tidak bulat lagi melainkan datar. Sehingga segala hal bisa dijangkau dalam sekejap. Globalisasi telah melahirkan masyarakat informasi baru yang setiap saat berasa liberal dengan kebebasan mendapatkan informasi serta kebebasan berekspresi.

Hal yang sama dalam penelitian ini di mana Katy Perry dalam video Chained to The Rhythm melalui berbagai diseminasi dalam teknologi komunikasi seperti media baru telah menjadikan video ini sebagai kultur bagi para fans serta mempengaruhi persepsi dan seolah-olah mengikat dunia bersama-sama dalam kebebasan berekspresi. 


\section{Analisis Semiótika}

Charles Sanders Peirce mendefinisikan semiotika sebagai "a relationship among a sign, an object, and a meaning (Suatu hubungan di antara tanda, objek, dan makna)." Charles Morris menyebut semiotika ini sebagai suatu "proses tanda, yaitu proses ketika sesuatu merupakan tanda bagi beberapa organisme" (Sobur, 2009, p. 16).

Semiotika berangkat dari tiga elemen utama, yang disebut Peirce teori segitiga makna atau triangle meaning. yang meliputi : a) Tanda adalah sesuatu yang berbentuk fisik yang dapat ditangkap oleh panca indera manusia dan merupakan sesuatu yang merujuk (merepresentasikan) hal lain di luar tanda itu sendiri. Acuan tanda ini disebut objek, b) Acuan Tanda (Objek) adalah konteks sosial yang menjadi referensi dari tanda atau sesuatu yang dirujuk tanda, c) Pengguna Tanda (Interpretant). Konsep pemikiran dari orang yang menggunakan tanda dan menurunkannya ke suatu makna tertentu atau makna yang ada dalam benak seseorang objek yang dirujuk sebuah tanda (Kriyantono, 2014, p. 265).

Menurut Hamad (2007:328), dalam kenyataannya wujud dari bentuk wacana dapat dilihat dalam beragam buah karya si pembuat wacana yang mencakup: a) Text (wacana dalam wujud tulisan) antara lain berita, features, artikel opini, cerpen, novel, dsb.; b) Talks (wacana dalam wujud ucapan) antara lain dalam wujud rekaman wawancara, obrolan, pidato, dsb.; c) Act (wacana dalam wujud tindakan) antara lain dalam wujud lakon drama, tarian, film, demonstrasi, dsb.; d) Artifact (wacana dalam wujud jejak) antara lain dalam wujud bangunan, lanskap, fashion, puing, dsb. Keberagaman bermacam bentuk wacana dapat kita temukan dalam media cetak (seperti novel), media audio (seperti pidato), media visual (seperti lukisan), media audiovisual (seperti film), di alam (seperti bangunan dan lanskap), atau discourse/ Discourse yang dimediasikan (seperti drama yang difilmkan).

Penelitian ini menggunakan analisis dalam bentuk media audiovisual dalam video Katy Perry yang berjudul Chained to The Rhythm yang mana ini merupakan wujud dari wacana yang berbentuk Act.

\section{Komunikasi Pesan Sosial}

Komunikasi, dari kata Latin Kommunicatio, artinya: hal memberitahukan, pemberitahuan, hal memberi bagian dalam, pertukaran. Kata 'Sosial' berasal dari kata Latin Socius, yang artinya : teman atau kawan. Namun kata 'Sosial', seperti halnya dalam ilmu-ilmu yang memakai kata itu (Sosiologi, Psikologi Sosial, dsb) tidak hanya terbatas pada arti harfiahnya, yakni teman atau kawan. Pengertian luas dari kata 'Sosial' mencakup lingkungan manusia yang dapat turut memberi pengaruh (langsung gatau tidak langsung) terhadap kita. Dengan demikian komunikasi sosial dapat diartikan secara umum sebagai suatu bentuk interaksi antar individu atau kelompok yang dilakukan dengan cara verbal maupun non verbal, dengan maksud untuk menyampaikan sesuatu pesan dengan cara yang dapat dipahami oleh kedua belah pihak, dan yang mampu menghasilkan tanggapan yang dapat dimengerti oleh kedua pihak (Gea, Wulandari, dan Babari, 2005:113-114).

Komunikasi berhubungan dengan perilaku manusia dan kepuasan terpenuhinya kebutuhan berinteraksi dengan manusia-manusia lainnya. Setiap orang membutuhkan hubungan sosial dengan orang - orang lainnya, dan kebutuhan ini terpenuhi melalui pertukaran pesan yang berfungsi sebagai jembatan untuk mempersatukan manusia yang satu dengan manusia lainnya, yang tanpa 
berkomunikasi akan terisolasi. Pesan - pesan ini mengemuka lewat perilaku manusia. Ketika kita berbicara, kita sebenarnya sedang berperilaku. Begitu juga ketika kita sedang melambaikan tangan, tersenyum, bermuka masam, menganggukkan kepala, atau memberikan suatu isyarat, kita sedang berperilaku. Perilaku-perilaku ini merupaka pesan-pesan, yang mana pesan-pesan itu digunakan untuk mengkomunikasikan sesuatu kepada orang lain (Anotnius et al., 2007, p. 113).

Katy Perry dalam video yang berjudul Chained to The Rhythm mencoba menyampaikan komunikasi pesan social kepada masyarakat saat ini yang berada di penghujung kemajuan peradaban umat manusia ekses globalisasi dan teknologi komunikasi.

\section{Post-modern}

Para ahli sosiolog dan pakarnya sebenarnya tengah berdebat apakah masyarakat kontemporer saat ini telah mengalami perubahan dan telah memasuki babak baru kehidupan yakni kehidupan masyarakat post-modern (Jameson, 1991; Kellner, 1989; Lemert and Gillan, 1994; Ritzer and Stepnisky, 2017). Sementara di saat yang sama, banyak ahli sosiolog masih berkutat pada bukti-bukti yang menyatakan bahwa masyarakat masih dalam babak yang sama yakni kehidupan masyarakat modern (Giddens, 2013).

Sebelum dibahas lebih mendalam, ada baiknya terdapat pengertian yang disepakati mengenai modern dan post-modern terlebih dulu. Menurut Anthony Giddens, modernitas mengacu pada bentuk kehidupan sosial dan organisasi yang muncul di Eropa pada kira-kira abad ke-17 dan sesudahnya yang pada gilirannya menancapkan pengaruhnya ke seluruh dunia (Giddens, 2013). Banyak istilah kemudian tumbuh dalam menggambarkan masa transisi ini antara lain masyarakat informasi atau masyarakat konsumen. Sedangkan post-modernisme sendiri dipopulerkan oleh Jean-Francois Lyotard (1985) yang menyebut post-modernisme sebagai pergeseran dari usaha untuk membumikan epistemologi dan dari keyakinan akan kemajuan yang direkayasa manusia. Sudut pandang post-modern melihat pluralitas klaim pengetahuan yang heterogen sehingga tidak terdapat ilmu pengetahuan yang memiliki posisi yang istimewa (Lyotard, 1984).

Perlu diketahui bahwa istilah post-modern ini cukup banyak meskipun sebenarnya mengandung arti dan penggunaan berbeda, tetapi banyak sekali pakar sosiologi yang menggunakan istilah secara lintas pada beragam situasi sehingga menghasilkan pengertian yang membingungkan. Bahkan Kellner (1989) menyebut post-modernisme telah menjadi "permainan terpanas di kota" (Kellner, 1989). Lemert menganjurkan untuk menghentikan istilah post-modernisme karena telah "letih oleh pekerjaan yang terlalu keras (Lemert and Gillan, 1994, p. 142). Artinya istilah itu telah banyak disalahgunakan baik oleh pendukungnya, oleh pencelanya, maupun selama berlangsung perdebatan panas antara semua pihak (Ritzer and Stepnisky, 2017, p. 586).

Post-modernitas mengacu pada periode historis yang umumnya dilihat menyusul era modern. Pengertian ini dipakai oleh Anthony Giddens dalam bukunya "konsekuensi-konsekuensi modernitas" dan Lyotard (1984). Post-modernisme mengacu pada produk kultural di bidang kesenian, film, arsitektur dan sebagainya yang berbeda dari produk kultural modern (Taylor, 2007). Sedangkan teori sosial postmodern mengacu pada cara berpikir yang berbeda dari teori sosial modern. Dengan demikian, istilah post-modern mengacu pada periode historis, produk kultural baru, 
dan tipe baru dalam penyusunan teori tentang kehidupan sosial (Ritzer and Stepnisky, 2017).

Secara historis menurut Lemert dalam Ritzer dan Stepnisky (2017), bahwa era post-modern ditandai kematian arsitektur modern pada 15 Juli 1972 saat dihancurkannya proyek perumahan Pruitt-Igoe di St. Louis. Contoh lain adalah perang terhadap kemiskinan yang dikampanyekan oleh Lyndon Johnson pada tahun 1960 an adalah cermin keyakinan masyarakat modern bahwa terdapat solusi riil untuk mengatasi kemiskinan. Pemerintahan selanjutnya yang dipimpin oleh Reagan di tahun 1980-an menyatakan enggan untuk membangun program raksasa guna mengatasi masalah kemiskinan. Sikap Reagan mencerminkan keyakinan masyarakat postmodern bahwa tak dada jawaban rasional tunggal untuk menanggulangi berbagai macam masalah. Dengan demikian dapat disimpulkan bahwa periode pemerintahan Kennedy dan Johnson dan Reagan telah bergerak dari masyarakat modern ke masyarakat post-modern.

Konsep kedua post-modern berkaitan dengan dunia kultural yang menyatakan produk post-modern cenderung menggantikan produk-produk modern. Melalui konsep kedua ini produk modern dan produk post-modern dapat dikenali perbedaannya dengan jelas. Blade Runner, misalnya digolongkan sebagai karya postmodern, sedangkan film Ten Commandments digolongkan sebagai karya modern.

Fredric Jameson $(1984,1991)$ membantu melukiskan post-modernitas. Ia menyederhanakan dan meletakkan beberapa elemen kunci gambaran kehidupan postmodern yakni (1) post-modernitas adalah sebuah dunia yang dangkal, dunia superfisial (misalnya hutan jelajah di Disneyland tidak sama dengan hutan sebenarnya); (2), post-modernitas adalah dunia yang kekurangan hubungan kasih sayang dan emosi; ketiga, post-modernitas adalah lenyapnya makna tempat seseorang dalam sejarah; sukar membedakan antara masa lalu, masa kini dan masa datang; (4) modernitas ditandai oleh teknologi produktif, eksplosif dan meluas (misalnya perakitan mobil), sedangkan post-modernitas didominasi oleh teknologi yang implisif, mendatar dan reproduktif (misal televisi). Dalam hal ini masyarakat post-modern sangat berbeda dari masyarakat modern (Jameson, 1991; Ritzer and Stepnisky, 2017). Dengan demikian, masyarakat post-modern dapat dengan mudah dikaitkan dengan tipologi masyarakat saat ini.

\section{Metode Penelitian}

Paradigma dalam penelitian ini menggunakan paradigma konstruktivisme. Paradigma konstruktivisme adalah paradigma pengetahuan yang berpegang pada pandangan yang menyatakan bahwa pengetahuan dan kebenaran obyektif merupakan hasil perspektif. Pengetahuan dan kebenaran diciptakan, tidak ditemukan oleh pikiran. Paradigma ini menekankan karakter realitas yang jamak dan lentur. Jamak dalam pengertian bahwa realitas bisa direntangkan dan dibentuk sesuai dengan tindakantindakan bertujuan dari perilaku manusia yang juga memiliki tujuan. (Ronda, 2018:14).

Konstruktivisme berangkat dari teori konstruktivisme Immanuel Kant (17241804) yang mengatakan bahwa pengetahuan adalah hasil konstruksi manusia. Paradigma ini digolongkan ke dalam penelitian subyektif (Poespowardojo and Seran, 2017, p. 141). 
Penelitian ini menggunakan pendekatan analisis semiotik atau seringkali disebut dengan analisis semiologi. Metode ini memungkinkan teks dapat diteliti dan mengandung makna tertentu yang berlaku baik secara konvensional maupun universal. Teks yang dimaksud dapat berupa isi yang dimuat di media dalam wujud apapun misalnya tayangan televisi, konser musik, berita surat kabar, fashion, menu masakan dan lainnya (Fiske, 1990; Pawito, 2005). Kajian semiotika meliputi tiga hal yakni pertama tanda itu sendiri, kedua kode atau sistem yang mana tanda diorganisasi, dan kultur dimana kode dan tanda tersebut berlaku (Fiske, 1990, p. 40). Pertama, analisis semiotik yang meliputi tanda mencakup studi pada berbagai macam tanda dari banyak cara untuk mengungkapkan makna dan cara tanda terhubung pada orang-orang yang menggunakannya. Karena tanda merupakan konstruksi manusia, maka hanya dapat dipahami dalam istilah penggunaannya dilakukan oleh orangorang. Artinya, tanda sendiri terdiri atas mempelajari variasi tanda dari banyak cara untuk mengungkap suatu makna serta cara makana tersebut berhubungan dengan orang-orang yang menggunakannya. Kedua, kode-kode atau sistem dimana tandatanda itu digunakan. Studi mengenai kode-kode atau sistem dimana tanda digunakan mencakup sejumlah cara bagaimana kode berkembang guna memenuhi kebutuhan komunitas dan kultur atau untuk memanfaatkan saluran komunikasi yang ada untuk menyalurkan pesan. Ketiga, kultur dimana kode-kode dan tanda digunakan. Studi tentang hal ini pada akhirnya terikat dengan bagaimana kode dan tanda digunakan karena eksistensi dan bentuknya (Fiske, 1990, chap. 3). Analisis semiotik akhirnya fokus pada teks. Dalam analisis ini, baik penerima atau pembaca dipandang lebih aktif daripada kebanyakan dalam teori komunikasi proses (linear). Kajian semiotik lebih memilih istilah "pembaca" daripada "penerima" karena mengandung tingkat keaktifan lebih tinggi daripada "penerima". Menurut analisis semiotik, "pembaca" melibatkan arti membaca mempelajari apa yang dilakukan karena itu ditentukan oleh pengalaman kultural pembaca itu sendiri. Pembaca membantu untuk menciptakan makna dari teks dengan membawanya pada ranah pengalaman, perilaku dan emosi yang dirasakan (Fiske, 1990, p. 40).

Tulisan ini menggunakan lirik Chained to the Rhythm dan adegan-adegan yang ditampilkan dalam musik video Chained to the Rhythm sebagai obyek untuk dikaji dalam konteks semiotika. Guna mendapat jawaban yang akurat maka validasi dilakukan dengan menerapkan metode semiotika. Metode semiotika mengandung arti bahwa kreativitas dan keaslian sering bermakna mengurai norma atau pemahaman dan análisis semiotika dapat membantu memahami norm apa yang terdeviasi, pada tingkat apa, dan apa dampaknya.

Teknik ini dilakukan dengan cara meamnfaatkan teks visual, utamanya yang terdapat pada suatu iklan, namun tidak membatasi pada bentuk teks visual lainnya seperti lirik atau kata-kata yang terdapat pada suatu video. Baik teks visual dan katakata yang muncul dalam suatu video berfungsi untuk saling menguatkan satu sama lain sehingga membentuk suatu norma yang menggugah kesadaran audiensinya.

\section{Hasil dan Pembahasan}

Penelitian ini menggunakan pendekatan analisis semiotik atau seringkali disebut dengan analisis semiologi. Metode ini memungkinkan teks dapat diteliti dan mengandung makna tertentu yang berlaku baik secara konvensional maupun universal. Namun lebih dari itu, video berdurasi empat menit itu juga dapat membantu mengenali bahwa masyarakat sosial saat ini tengah bergerak ke arah 
kehidupan post-modern bahkan dapat dikatakan video ini menjadi bukti pintu bahwa kehidupan masyarakat tengah meninggalkan modernitas.

Pada permulaan video di menit ke 0.03, Katy Perry menampilkan gambar hamster dengan mata yang berputar-putar di sampingnya terdapat tulisan "Oblivia". Hamster adalah makhluk yang lucu sekaligus menggemaskan. Kehidupan hamster sehari-harinya gemar sekali bermain roda berputar di dalam kandangnya. Hamster yang bermain dalam Hamster disini memiliki makna konvensional sebagai penanda masyarakat yang tengah memasuki kehidupan yang menjemukan. Masyarakat berpikir tengah melaju ke suatu kemajuan, nyatanya masyarakat saat ini seolah berjalan di tempat.

"Oblivia" menurut kamus daring Thesaurus berasal dari kata "oblivion" yang mengandung arti (1) suatu kondisi tidak mengetahui apapun, (2) suatu kondisi melupakan kesadaran yang dimiliki, dan (3) suatu tindakan menuju kepunahan (Kamus Thesaurus, 2018). Taman bermain lagi-lagi menunjukkan “Oblivia” yang sengaja dipilih yang juga penanda untuk merujuk pada sesuatu yang serba indah.

Video dikemas dengan latar belakang taman bermain dan menampilkan pameran gaya hidup modern. Busana yang dikenakan seolah ingin meneguhkan bahwa masyarakat tengah hidup di puncak kemajuan peradaban. Hal ini juga diperkuat dengan penggunaan gawai yang menjadi ciri khas kehidupan saat ini yang tidak bisa lepas dari hiruk pikuk teknologi dan arus informasi. Sekeliling taman hiburan menampilkan warna warni yang memanjakan mata dan berbagai wahana yang elok dipandang dan menarik untuk dicoba.

Musik video "Chained to the Rhythm" menjadi populer. Musik video ini telah menduduki papan atas musik di berbagai negara ("Katy Perry: Chained to the Rhythm breaks Spotify streaming record | EW.com," 2017, "Katy Perry's Chained To The Rhythm has already been smashing records on Spotify | Metro News," 2017, "Katy Perry's Chained To The Rhythm sets new Spotify record," 2017). Hal ini tidak lepas dari kepiawaian memainkan tanda yang seolah menggugat kesadaran masyarakat agar tidak terseret arus. Berikut adalah macam-macam symbol dan tanda di balik video musik "Chained To the rhythm":

Pertama, di pintu masuk Oblivia, video musik menyuguhkan pengunjung yang tidak bisa lepas dengan gawainya. Para turis asik berswafoto dan sesaat berhenti sejenak sambil diiringi oleh lirik "so comfortable we cannot see the trouble, trouble". Saking asyiknya dengan gawai masing-masing, para turis tidak memperhatikan hal-hal di sekitarnya.

Selanjutnya, terdapat wahana yang disebut "Love". Wahana ini berupa terowongan yang dipenuhi oleh emoticon yang banyak dipakai di sosial media. Katy Perry beserta kawannya melalui wahana tersebut sambil mengumpulkan emoticon sebanyak mungkin. Jumlah emoticon yang berhasil dikumpulkan menentukan popularitas setiap penumpang di akhir wahana. Emoticon ini sebagai penanda bahwa popularitas ditentukan oleh jumlah tanggapan yang paling banyak dapat diperoleh dari media sosial. Adegan ini hendak menyadarkan masyarakat akan fenomena popularitas instan yang saat ini sangat mudah diperoleh dengan berbagi informasi yang mendapat tanggapan paling banyak.

Hal ini selaras dengan yang dinyatakan oleh Geger Riyanto (2018), ia menyebut masyarakat saat ini merasa mereka lebih hidup dengan adanya pengakuan, 
keberadaan keterlibatan insan lain. Pendapat Geger Riyanto tersebut mempertegas apa yang pernah Emile Durkheim nyatakan jauh sebelumnya yakni, masyarakat memperoleh sensasi hidup dari kebersamaan dengan yang lain (Riyanto, 2018). Perbedaan yang terjadi antara masyarakat di jaman pra modern yang kental dengan masyarakat tradisional memperoleh kebersamaan melalui keakraban dari tatap muka dan komunikasi sehari-hari. Di era digital saat ini, utamanya era yang diyakini oleh Fredric Jameson, kebersamaan masyarakat justru semakin longgar (Jameson, 1991). Ini yang menjadi ciri-ciri era post-modern.

Bunga Mawar yang ditampilkan dalam video musik tersebut, menggugah kesadaran Katy Perry. Fiske dalam bukunya menarasikan "Bunga Mawar" dengan banyak metafora visual, antara lain salah satunya adalah perayaan ("Flower Meanings by Type, Name, Color and Occasion," 2018). Hal yang indah ini lantas jika disandingkan dengan gambaran yang terjadi berikutnya akan membangun norma yang berbeda. Bahwa Bungan Mawar melukai Katy Perry, menjadi penanda bahwa hal yang indah dapat melukai. Bahwa hiburan dan hingar bingar taman hiburan bersifat semu dan berujung dapat pada masalah.

Wahana lain yang menjadi sorotan adalah wahana bernama "American Dream Drop". Tulisan "American Dream Drop" merupakan bentuk metáfora visual paling dominan yang membawa deviasi norma. Wahana ini berbentuk rumah impian yang menawarkan penggunanya untuk diangkat ke tempat yang tinggi lalu kemudian dijatuhkan secara tiba-tiba sampai wahana tersebut runtuh hingga beberapa bagiannya terlepas. Berdasarkan cuplikan video maka terdapat dua metáfora visual yang diangkat yakni "rumah" dengan tulisan "dream" serta "kejatuhan". Menurut Fiske (1990, p. 103) norma adalah hal penting yang merelasikan apa yang dicitrakan dan dilihat dengan bawah sadar kita. Berdasarkan itu, maka "rumah" dan "kejatuhan" hingga bagiannya terlepas mengingatkan pada sektor properti yang menjadi penyebab crisis 2008 lalu("Housing blew up the global economy in 2008 and we learned nothing | Housing Network | The Guardian," 2016). Ini mengingatkan masyarakat pada krisis finansial tahun 2008 lalu yang dipicu oleh kenaikan harga properti yang tinggi sehingga mengakibatkan banyak kredit macet.

Ketiga, tulisan billboard dengan gambar hamster merupakan penanda berikutnya. Adegan ini kemudian diikuti oleh kelompok orang yang sedang berjuang mengantri untuk menaiki wahana seperti yang terdapat dalam setiap kandang hamster. Sekelompok orang bersedia menunggu meskipun mereka harus menunggu sebanyak 1.987 antrian. Kelompok orang ini begitu semangat untuk dengan sukarela hanya untuk berputar-putar di tempat yang sama. Adegan ini diiringi oleh lirik "are we crazy. "Apa kita sudah gila? Menjalani hidup lewat kamera, terjebak di dalam pagar yang kita buat sendiri. Seperti hiasan, yang nyaman, tapi sebenarnya kita hanya hidup di antara hal yang semu belaka. Kita tidak dapat melihat bahwa ada masalah di balik ini semua", Katy Perry sendiri tidak terjatuh dalam wahana ini tetapi berhenti lari di wahana ini seakan menyadari sesuatu.

Wahana "No Place Like Home", pada adegan ini pengunjung akan diketapel ke atas sampai melewati pagar putih tinggi yang bertuliskan "safe trip home" arti dari adegan ini menggambarkan polemik pagar batas Amerika Serikat-Meksiko dan retorika xenophobic yang menyuruh imigran untuk kembali ke tempat asal. Bukan rahasia umum lagi bahwa Presiden Donald Trump hendak membangun pagar tinggi di sepanjang batas Meksiko untuk menghalau imigran ilegal masuk ke tanah 
AS(“Trump: 'We will build the wall' | The daily briefing | US news | The Guardian," 2017). Hal ini banyak menuai kecaman karena seolah menguatkan sentimen xenophobia ke seluruh antero AS. Presiden Donald Trump berharap hal ini sanggup membawa Amerika Serikat lebih baik di masa pemerintahannya. Katy Perry pun menyematkan "Thought we can do better than that / I hope we can" dalam lirik bersamaan dengan melempar sepasang orang kulit berwarna ke luar pagar bertuliskan "Safe trip home".

Wahana "Boms Away", kapsul yang berbentuk seperti bom nuklir, setelah boms away kamera langsung berpindah ke kembang gula kapas yang bentuknya mirip awan jamur artinya mirip awan yang terbentuk setelah ledakan bom nuklir kita juga bisa lihat bahwa video tersebut bernuansa tahun 1950'an karena pada zaman itu banyak sekali serangan nuklir.

Minuman Fire Water, adalah minuman yang disediakan di Oblivia dan mudah terbakar, nama kafe yaitu "Inferno H20". Lebih banyak SPBU (Stasiun Pengisian Bahan bakar Umum) bensin yang berubah menjadi warung tempat nongkrong, Katy Perry menari diantara penari berseragam pelaut arti dari adegan ini adalah air minum yang telah tercemar atau krisis air bersih di dunia khususnya Asia yang bisa menjadi perang dunia, bisa juga menggambarkan ketergantungan terhadap minyak mentah, sebuah subtansi yang mudah terbakar peranannya sangat menentukan di ekonomi global, sama seperti air. Membakar minyak atau bahan bakar lainnya akan berkontribusi pada global warming (pemanasan planet).

Adegan Klimaks kacamata 3D, Lagu menjelang akhir Katy Perry duduk dengan kacamata 3D bersama kerumunan menyaksikan salah satu pertunjukan di layar yang kemudian dari balik pertunjukan itu muncul penyanyi kolaborasi Skip Marley yang melantunkan dengan gaya khas reggae. Jawaban dari lirik lagu ini adalah Hancurkan tembok untuk kita saling terhubung. Waktu terus berjalan untuk sebuah kekuasaan. Kita akan menuju kehancuran, maka bangunlah, bangkitlah. Yang artinya sebuah pendapat atas kekuasaan yang meresahkan masyarakat. Harapannya dapat menggugah kesadaran masyarakat untuk keluar dari "hiburan semu".

Video musik ini kemudian ditutup dengan adegan yang memperlihatkan seluruh pengunjung duduk manis menonton televisi ukuran besar. Sementara di depannya lima orang yang berperan menampilkan suatu keluarga yang harmonis. Ketika televisi ditampilkan, maka seketika langsung teringat pada pernyataan Fredric Jameson yang menyebut teknologi impilsif dan reproduktif merupakan ciri kehidupan masyarakat post-modern (Jameson, 1991; Ritzer and Stepnisky, 2017).

Lagu "Chained to the Rhythm" dapat dianalisis menggunakan analisis semiotik. Lagu ini menurut pilihan kata yang digunakan dalam liriknya mengajak publik untuk mempertanyakan isu-isu sosial dan politik terutama di Amerika Serikat. Bersamaan dengan itu, lagu ini mengajak masyarakat informasi untuk sadar akan kehidupan mereka yang tengah berubah. Perubahan masyarakat terjadi karena masyarakat berangsur kehilangan kontrol untuk mengontrol arus informasi dan apa yang disebut oleh Anthony Giddens juggernaut atau panser raksasa (Giddens, 2013).

Musik Video "Chained to the Rhythm" termasuk pada karya post-modern. Dikatakan demikian, karena video ini menceritakan masyarakat informasi kemudian larut dalam teknologi-teknologi baru yang hadir sebagai hiburan. Fredric Jameson menyebut dua karakter penting post-modern adalah kehadiran teknologi yang impilsif 
dan reproduktif seperti televisi. Dapat kita lihat Katy Perry menampilkan adegan dimana seluruh pengunjung di akhir hiburan disuguhi oleh layar televisi ukuran besar. Televisi ini seolah menjadi tolok ukur modernitas kehidupan masyarakat. Selain itu pengunjung juga diwajibkan menggunakan kacamata 3-dimensi yang berfungsi untuk menampilkan agar tontonan televisi menjadi senyata pada kehidupan riil. Pada kenyataan, citra yang ditangkap oleh mata melalui kacamata 3D mengaburkan realitas yang ada di depan mata. Fredric Jameson dalam tulisannya kembali mengingatkan, masyarakat post-modern erat dengan produk yang superfisial, misalnya hutan di tayangan Disneyland tidak sama dengan gambaran hutan yang sebenarnya di dunia nyata.

Secara keseluruhan, video musik "Chained to the Rhythm" hendak mengenalkan pada masyarakat luas dampak destruktif masyarakat informasi. Masyarakat informasi sangat rentan terhadap manipulasi yang disebarkan melalui teknologi produktif yakni televisi dan telepon pintar. Masyarakat tidak merasakan bahwa mereka tengah digiring pada suatu ketidakmapanan. Masyarakat tidak menyadari bahwa hasrat untuk menuntut pergolakan untuk keluar dari kerangka besi telah dibuat pudar secara perlahan. Weber sendiri telah memprediksi hal ini terjadi bahwa semakin modern masyarakat maka ia semakin lama merasa hidup di suatu kerangka besi yang rasionalitasnya dapat dibentuk secara instan (Ritzer and Stepnisky, 2017). Anthony Giddens menyebut masyarakat tersebut dengan masyarakat konsumen yang mudah digerakkan dengan tayangan dan tawaran instan lewat media televisi dan iklan kilat di laman-laman web tertentu(Giddens, 2013; Ritzer and Stepnisky, 2017).

Emoticon ini sebagai penanda bahwa popularitas ditentukan oleh jumlah tanggapan yang paling banyak dapat diperoleh dari media sosial("How emojis became the modern world's status symbols - and how they've crossed from messaging apps to real life | South China Morning Post," 2017; Ljubešić and Fišer, 2016). Adegan ini hendak menyadarkan masyarakat akan fenomena popularitas instan yang saat ini sangat mudah diperoleh dengan berbagi informasi yang mendapat tanggapan paling banyak. Banyak fenomena yang dapat menjadi contoh popularitas instan ini sehingga muncul istilah seperti selebgram dan seleb twitter.

Hal ini selaras dengan yang dinyatakan oleh Geger Riyanto (2018), ia menyebut masyarakat saat ini merasa mereka lebih hidup dengan adanya pengakuan, keberadaan keterlibatan insan lain. Pendapat Geger Riyanto tersebut mempertegas apa yang pernah Emile Durkheim nyatakan jauh sebelumnya yakni, masyarakat memperoleh sensasi hidup dari kebersamaan dengan yang lain (Riyanto, 2018). Perbedaan yang terjadi antara masyarakat di jaman pra modern yang kental dengan masyarakat tradisional memperoleh kebersamaan melalui keakraban dari tatap muka dan komunikasi sehari-hari. Di era digital saat ini, utamanya era yang diyakini oleh Fredric Jameson, kebersamaan masyarakat justru semakin longgar (Jameson, 1991). Ini yang menjadi ciri-ciri era post-modern. "Chained to the rhythm" mengajarkan terdapat kelonggaran kebersamaan dalam masyarakat di kehidupan post-modern. Masyarakat

Video "Chained to the rhythm" yang lahir dari perkembangan teknologi komunikasi dan ekses dari globalisasi dengan kecanggihan teknologinya yang mampu mempengaruhi para penggemarnya yang mana sesuai dengan teori media ekologi yang menekankan tentang bagaimana individu dalam masyarakat berpikir, merasa serta bertindak termasuk pengaruh video ini pada budaya manusia dalam berkomunikasi. Yang mana menurut teori ini, media memperbaiki persepsi kita dan 
mengelola pengalaman kita dengan pesatnya perkembangan teknologi informasi dan komunikasi yang membuat segalanya serba viral dan instan. Yang mana menurut video ini masyarakat seolah-olah memperoleh sensasi hidup dari kebersamaan dengan yang lain yang terintegrasi dengan efek dari video ini. Efek dari video ini yang membawa Jiwa sosialnya terjalin lagi dari yang tadinya melemah, sebab merasa bahwa tidak memerlukan bantuan orang lain yang telah tergantikan dengan teknologi sebagai solusinya. Menurut teori media ekologi, video ini mengikat dunia penggemarnya bersama-sama dalam suatu kondisi masyarakat post-modern yang tadinya mengalami anti-sosial yang kepada tetangga dekat kurang begitu akrab karena telah memiliki komunitas sendiri, efek dari teknologi yang tak terbatas ruang dan waktu.

\section{Kesimpulan}

Musik dapat menjadi media untuk menyalurkan argumentasi dan pendapat politik yang dimiliki oleh seorang musisi. Musik dapat menjadi wadah untuk mengkritik kebijakan rezim yang sedang berkuasa. Oleh karena itu, musik dapat memiliki sejumlah makna yang muncul dari bagaimana musik video ditampilkan dan lirik menjadi penguat makna tersebut. Musisi dengan musikalitas di atas sudah cukup banyak, Iwan Fals salah satunya. Namun di awal tahun 2017, Katy Perry mampu menampilkan suatu musik video dengan musikalitas yang tinggi. Makna dan penanda yang disampaikan dalam musik video berjudul "Chained to the Rhythm" menjadi sangat relevan dengan konteks pertama kemenangan Presiden AS Donald Trump yang berimbas pada serangkaian kebijakan yang dianggap kontroversial oleh sebagian besar khalayak baik warga Amerika Serikat maupun dunia internasional, dalam aspek yang lebih luas video musik ini juga bermakna kehidupan post-modern yang ditandai oleh tindakan-tindakan akibat dari teknologi yang cenderung impilsif dan reproduktif seperti televisi dan telepon pintar pada level berikutnya. Teknologi dalam suatu masyarakat modern menentukan tindakan-tindakan yang dilakukan oleh masyarakat yakni menuju ke suatu ketidakaturan, kelonggaran dalam bermasyarakat, terlalu terikat pada teknologi dengan segala kemudahan namun lupa akan realitas sebenarnya. Oleh karena itu tidak heran jika Katy Perry menyebut masyarakat postmodern telah terlena dengan Oblivia.

\section{Daftar Pustaka}

Anotnius, A. gea, Wulandari, antonia P.Y., Babari, Y., 2007. Character Building II: relasi dengan diri sendiri. Elex Media Komputindo, Jakarta.

Awe, M., Fals, I., 2005. Fals: nyanyian di tengah kegelapan. Ombak.

Diomena, Suyanto, 2015. Representasi Sosial dan Politik di Amerika dalam Lirik Lagu American Idiot Karya Kelompok Musik Green Day. Fakultas Ilmu Sosial dan Ilmu Politik Universitas Riau Vol 2, No 2 (2015): Wisuda Oktober 2015.

Fiske, J., 1990. Introduction to Communication Studies, Studies in communication. Routledge.

Flower Meanings by Type, Name, Color and Occasion [WWW Document], 2018. . The Flower Expert. URL http://www.theflowerexpert.com/content/aboutflowers/flowermeanings (accessed 10.10.18).

Giddens, A., 2013. The Consequences of Modernity, Social theory. Wiley. 
Green Day song meanings: American Idiot - GeekStinkBreath.net [WWW Document], n.d. . Geek Stink Breath. URL http://www.geekstinkbreath.net/greenday/songmeanings/american-idiot/ (accessed 4.11.18).

Griffin, E., 2014. A First Look at Communication Theory.

Housing blew up the global economy in 2008 and we learned nothing | Housing Network | The Guardian [WWW Document], 2016. URL https://www.theguardian.com/housing-network/2016/jan/29/housing-globaleconomy-2008-the-big-short-financial-crash (accessed 10.10.18).

How emojis became the modern world's status symbols - and how they've crossed from messaging apps to real life | South China Morning Post [WWW Document], 2017. URL https://www.scmp.com/lifestyle/article/2083504/how-emojis-became-modernworlds-status-symbols-and-how-theyve-crossed (accessed 10.10.18).

Jameson, F., 1991. Postmodernism, Or, The Cultural Logic of Late Capitalism, Postcontemporary interventions. Duke University Press.

Kamus Thesaurus, 2018. Oblivion | Define Oblivion at Dictionary.com [WWW Document]. Thesaurus Online. URL http://www.dictionary.com/browse/oblivion (accessed 3.26.18).

Katy Perry: Chained to the Rhythm breaks Spotify streaming record | EW.com [WWW Document], 2017. URL https://ew.com/music/2017/02/11/katy-perry-chained-tothe-rhythm-spotify-streaming-record/ (accessed 10.10.18).

Katy Perry's Chained To The Rhythm has already been smashing records on Spotify $\mid$ Metro News [WWW Document], 2017. URL https://metro.co.uk/2017/02/12/katyperrys-chained-to-the-rhythm-has-already-been-smashing-records-6443030/ (accessed 10.10.18).

Katy Perry's Chained To The Rhythm sets new Spotify record [WWW Document], 2017. URL http://www.officialcharts.com/chart-news/katy-perrys-chained-to-therhythm-sets-new-spotify-record_18202/ (accessed 10.10.18).

Kellner, D., 1989. Critical Theory, Marxism, and Modernity, Parallax (Baltimore, Md.). Johns Hopkins University Press.

Kriyantono, R., 2014. Teknik Praktis Riset komunikasi. Kencana.

Lemert, C.C., Gillan, G., 1994. Michel Foucault: Social Theory and Transgression. UMI Books on Demand.

Littlejohn, S.W., Foss, K.A., 2009. Encyclopedia of Communication Theory. SAGE.

Ljubešić, N., Fišer, D., 2016. A Global Analysis of Emoji Usage, in: Proceedings of the 10th Web as Corpus Workshop. Presented at the Proceedings of the 10th Web as Corpus Workshop, Association for Computational Linguistics, Berlin, pp. 82-89. https://doi.org/10.18653/v1/W16-2610

Lyotard, J.F., 1984. The Postmodern Condition: A Report on Knowledge, Theory and history of literature. University of Minnesota Press.

Moeloeng, L.J., 2018. Metodologi Penelitian Kualitatif, 38th ed. Remaja Rosdakarya.

Nadjib, E.A., 2015. Gelandangan di Kampung Sendiri: Pengaduan Orang-Orang Pinggiran. Bentang. 
Pawito, 2005. Budaya Pop dan Politik: Analisis Semiotik terhadap Penampilan Iwan Fals di TRANS TV, 4 April 2004. Jurnal Ilmu Komunikasi Vol 2, No 1 (2005).

Poespowardojo, T.M.S., Seran, A., 2017. Diskursus TEORI-TEORI KRITIS: Kritik atas Kapitalisme Klasik, Modern, dan Kontemporer. Kompas.

Ritzer, G., Stepnisky, J., 2017. Modern sociological theory. SAGE Publications.

Riyanto, G., 2018. Media Sosial dan "Hydra" Kebencian [WWW Document]. Media Sosial dan Hydra Kebencian. URL https:/ / kompas.id/baca/opini/2018/03/24/media-sosial-dan-hydra-kebencian/ (accessed 3.26.18).

Sobur, A., 2009. Analisis teks Media: suatu pengantar untuk analisis wacana, analisis smeiotik, dan analisis framing. Remaja Rosdakarya, Bandung.

Subhan SD, M., 2018. Iwan Fals [WWW Document]. URL https://kompas.id/baca/x/ politik/2017/07/06/iwan-fals/ (accessed 3.29.18).

Tributes paid to Charles Kennedy, 2015. . BBC News.

Trump: "We will build the wall" | The daily briefing | US news | The Guardian [WWW Document], 2017. URL https://www.theguardian.com/usnews/2017/jan/25/donald-trump-mexico-border-wall-executive-order (accessed 10.10.18).

KatyPerryVEVO, 2017. Katy Perry - Chained To The Rhythm (Official) ft. Skip Marley 